\title{
Restoration of Functional Glycosylation of $\alpha$-Dystroglycan in FKRP Mutant Mice Is Associated with Muscle Regeneration
}

\author{
Hiroyuki Awano, Anthony Blaeser, Elizabeth Keramaris, Lei Xu, Jason Tucker, Bo Wu, Pei Lu, and Qi L. Lu
}

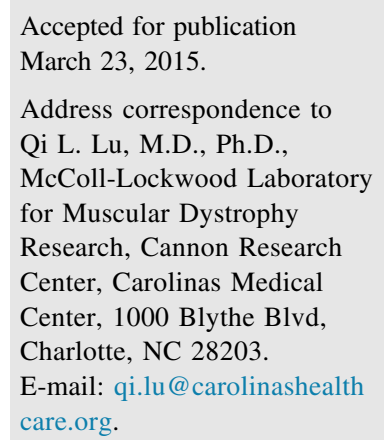

Address correspondence to Qi L. Lu, M.D., Ph.D., McColl-Lockwood Laboratory for Muscular Dystrophy Research, Cannon Research Center, Carolinas Medical Center, 1000 Blythe Blvd, Charlotte, NC 28203.

E-mail: qi.lu@ carolinashealth care.org.

\begin{abstract}
Mutations in fukutin-related protein (FKRP) gene are characterized with lack of functionally glycosylated $\alpha$-dystroglycan (F- $\alpha$-DG). Surprisingly, a few muscle fibers express strong $F-\alpha$-DG. Herein, we investigated the restoration of $\mathrm{F}-\alpha-\mathrm{DG}$ in the FKRP mutant muscles and showed that the restoration of glycosylation is associated with muscle regeneration and dependent on the expression of both like-glycosyltransferase (LARGE) and partially functional FKRP. F- $\alpha$-DG in the regenerating fibers reaches up to normal levels and lasts for $>4$ weeks, but no up-regulation of the LARGE and FKRP is detected during the regeneration process. The FKRP protein with $P 448 \mathrm{~L}$ mutation is sufficient for functional glycosylation of $\alpha$-DG in regenerating fibers, but not in mature fibers. Thus, factors other than FKRP enable regenerating fibers to produce functional $\alpha$-DG, compensating for the defect in FKRP function. Identification of factors other than LARGE and FKRP could generate new approaches for restoration of F- $\alpha$-DG in mature muscle fibers with defects in FKRP functions. (Am J Pathol 2015, 185: 2025-2037; http://dx.doi.org/10.1016/j.ajpath.2015.03.017)
\end{abstract}

The dystrophin-glycoprotein complex is crucial for the maintenance of muscle membrane stability by providing a physical linkage between the actin cytoskeleton and the extracellular matrix. ${ }^{1-3}$ Dystroglycan (DG) is an essential component of the dystrophin-glycoprotein complex., The polypeptide is post-translationally cleaved into two subunits, $\alpha$-DG and $\beta$-DG. ${ }^{6} \alpha-\mathrm{DG}$ is extensively glycosylated with both $N$ - and $O$-linked glycans and acts as a cellular receptor for laminin and other proteins, including agrin, perlecan, neurexin, and pikachurin. ${ }^{7-13}$ The interaction of $\alpha$-DG with extracellular matrix proteins largely depends on $O$-linked glycosylation in the mucin-like domain (central region) of the $\boldsymbol{\alpha}$-DG. ${ }^{2,14-20}$

Recently, a subset of muscular dystrophies, known as dystroglycanopathies, has been characterized by a common secondary defect in DG glycosylation. The defect is related to autosomal-recessive mutations in at least 16 different genes. They include fukutin-related protein $(F K R P){ }^{21}$ fukutin $(F K T N){ }^{22}$ like-acetylglucosaminyltransferase $(L A R G E),{ }^{23}$ POMGNT1, ${ }^{24}$ POMT1, ${ }^{25}$ POMT2, ${ }^{26}$ isoprenoid synthase domain containing (ISPD), ${ }^{27,28}$ transmembrane protein 5 (TMEM5), ${ }^{29} \beta 1,3-\mathrm{N}$-acetylglucosaminyltransferase1
(B3GNT2), ${ }^{30}$ glycosyltransferase-like domain containing 2 (POMGNT2), 33 -N-acetylgalactosaminyltransferase 2 (B3GALNT2), ${ }^{32}$ DOLK, ${ }^{33}$ GMPPB ${ }^{34}$ DPM $2,{ }^{35}$ DSPP, and $P O M K{ }^{36,37}$ Several studies have suggested that these genes are involved in post-translational glycosylation modifications of $\boldsymbol{\alpha}$-DG. ${ }^{21,23,24-26,38-40}$

To investigate the functional roles of FKRP in muscular dystrophies, we have previously generated two different FKRP mutant mice exhibiting similar dystrophic phenotypes, as observed in patients with $F K R P$ mutations. $\mathrm{P} 48 \mathrm{~L}^{+}$mice contain a homozygous missense mutation (c.1343C $>\mathrm{T}$, p.Pro448Leu) in the FKRP gene with the neomycin-resistant $\left(\mathrm{Neo}^{\mathrm{r}}\right)$ cassette, and their phenotype largely represents congenital muscular dystrophy with central nerve system involvement. ${ }^{41}$ The other FKRP mutant mouse had the same P448L mutations, but the $\mathrm{Neo}^{\mathrm{r}}$ cassette was removed from the insertion site of the mutation $\left(\mathrm{P}_{448 \mathrm{~L}^{-}}\right.$mice). The $\mathrm{P} 448 \mathrm{~L}^{-}$ homozygotes showed muscle weakness demonstrated by the

\footnotetext{
Supported by the Carolinas HealthCare Foundation Carolinas Muscular Dystrophy Research Endowment.

Disclosures: None declared.
} 
limb muscle retraction, elevated serum creatine kinase and alanine aminotransferase levels, and dystrophic pathology associated with limb-girdle muscular dystrophy without clear defect in the central nervous system. ${ }^{42}$ Our characterization study showed that the levels of functionally glycosylated $\alpha$-DG (F- $\alpha$-DG) also vary in correlation with mutation types. Most muscle fibers in the FKRP mutant mice with common L276I mutations maintain expression of F- $\alpha$-DG, but at significantly reduced levels. However, nearly all muscle fibers in both the $\mathrm{P} 448 \mathrm{~L}^{+}$and $\mathrm{P} 448 \mathrm{~L}^{-}$mutant mice lack $\mathrm{F}-\alpha-$ DG. Only a small proportion of skeletal muscle fibers expressing F- $\alpha$-DG (referred to as revertant fibers) can be clearly demonstrated by the IIH6 antibody in the P448 $\mathrm{L}^{-}$ mutant mice.

Herein, we compared the patterns of revertant fibers in the muscles of two P448L mutant and LARGE mutant $\left(L A R G E^{\text {myd }}\right.$ ) mice to dissect the mechanism(s) of reversion of $\mathrm{F}-\alpha$-DG in skeletal muscle of dystroglycanopathy. Revertant fibers were examined during muscle regeneration, and expression profiling of mutant muscles was compared with normal controls to reveal potential correlation between $\mathrm{F}-\alpha-\mathrm{DG}$ and patterns of gene expression. The results suggest that factors other than FKRP and $L A R G E$, unique to regenerating fibers and yet to be identified, are involved in the restoration of $\mathrm{F}-\alpha$-DG.

\section{Materials and Methods}

\section{Animals and Ethical Statement}

This study was performed in strict accordance with the recommendations in the Guide for the Care and Use of Laboratory Animals ${ }^{43}$ of the NIH. The protocol (number 01-13-03A) was approved by the Committee on the Ethics of Animal Experiment of the Institutional Animal Care and Use Committee, Carolinas Medical Center (Charlotte, NC). All treatment was performed under isoflurane anesthesia, and every effort was made to minimize suffering.

The $P 448 L^{+}, P 448 L^{-}, L A R G E^{m y d}$ (Jackson Laboratory, Bar Harbor, ME), and C57BL/6 (C57) mice were used. We used two age groups, 3 to 6 weeks and 6 months old, for $P 448 L^{-}$and $C 57$ mice. Only the young age group of 3- to 6week-old $P 448 L^{+}$and $L A R G E^{\text {myd }}$ mice was examined because of their limited life span.

\section{NTX and PEI Experiment}

To induce a skeletal muscle regeneration, followed by degeneration, notexin (NTX; $40 \mu \mathrm{L}$ at $5 \mu \mathrm{g} / \mathrm{mL}$; Latoxan, Valence, France) ${ }^{44}$ and polyethylenimine [PEI; branched, molecular weight (MW), $25 \mathrm{kDa} ; 40 \mu \mathrm{L}$ at $0.5 \mu \mathrm{g} / \mu \mathrm{L}$; Sigma, St. Louis, $\mathrm{MO}]$ were injected into the one muscle. Injection of the reagent was applied to only one side leg of the mice. The contralateral leg without treatment was used as a control. Tibialis anterior (TA) muscle was examined at 2, 4, 7, 14, and 28 days for $P 448 L^{-}$and $C 57$, and at 4 and 14 days in $\mathrm{P}_{448 L^{+}}$and
$L A R G E^{\text {myd }}$ because of limited mouse availability. Three mice were used for each treatment group. To separate the regenerating muscle fibers after toxin treatment from remaining untreated muscle tissue, the injected muscle sections were examined under a light microscope to identify the injected area with needle tracts, degenerating fibers, and regenerating fibers. The muscle tissue surrounding the injected area was trimmed off from the frozen tissue block. The sections from the remaining injected areas were then cut and collected for RNA and protein extraction.

\section{Histology and Immunohistochemistry}

TA muscles were snap frozen in isopentane chilled with liquid nitrogen. Cross sections ( $6 \mu \mathrm{m}$ thick) were cut from the frozen tissues and stained with hematoxylin and eosin. Immunohistochemical staining of F- $\alpha$-DG was performed on cross sections of the muscle fixed with ice-cold $50 \%$ ethanol and 50\% acetic acid for 1 minute, and blocked with $8 \%$ bovine serum albumin in double-distilled water for 1 hour. Primary antibody against $\alpha$-DG (IIH6C4; Millipore, Temecula, CA) in $1 \%$ bovine serum albumin at 1:500 dilutions was incubated overnight at $4{ }^{\circ} \mathrm{C}$. For embryonic myosin heavy chain (eMyHC) immunostaining (F1.652; Developmental Studies Hybridoma Bank, Iowa City, IA), sections were incubated with $1 \%$ horse serum for 1 hour, followed by primary antibodies, washed for 10 minutes three times with phosphate-buffered saline, and finally incubated with Alexa Fluor 488-conjugated anti-mouse or Alexa Fluor 594-conjugated anti-rabbit secondary antibodies (Life Technologies, Carlsbad, CA) at 1:500 dilution. Sections were also stained with secondary antibody only as negative controls.

Immunofluorescence was visualized using an Olympus BX51 fluorescent microscope (Opelco, Dulles, VA). Images were captured using an Olympus DP70 charge-coupled device camera system (Opelco) at standard gain and same exposure time. Fiber diameter was determined by measuring the shortest axis for all fibers within maximal cross-sectional areas of TA muscle using MetaMorph (Molecular Devices LLC, Sunnyvale, CA).

\section{Protein Extraction}

For Western blot analysis, total proteins were extracted from TA muscles and cells using TX-100 lysis buffer [1\% Triton $\mathrm{X}-100,50 \mathrm{mmol} / \mathrm{L}$ Tris $(\mathrm{pH} 8.0), 150 \mathrm{mmol} / \mathrm{L} \mathrm{NaCl}$, and $0.1 \%$ SDS] supplemented with protease inhibitor cocktail (Roche, South San Francisco, CA). For cytokine analysis, NP-40 lysis buffer [1\% NP-40, $50 \mathrm{mmol} / \mathrm{L}$ Tris $(\mathrm{pH} 8.0$ ), and $150 \mathrm{mmol} / \mathrm{L} \mathrm{NaCl}$ ] with protease inhibitor cocktail was used. Samples were homogenized in lysis buffer, and the supernatants were collected by centrifugation at $16,000 \times g$ for 10 minutes. Protein concentration was determined by modified Lowry assay (DC protein assay; Bio-Rad, Hercules, CA). 


\section{Western Blot Analysis}

The lysates were loaded onto $4 \%$ to $20 \%$ Tris-glycine gel (Invitrogen, Carlsbad, CA). The proteins were transferred to polyvinylidene difluoride membranes with constant current at $200 \mathrm{~mA}$ for 2 hours in a cold room $\left(4^{\circ} \mathrm{C}\right)$. Polyvinylidene difluoride membranes were incubated with protein-free T20 blocking buffer (Pierce, Rockford, IL). The antibodies against $\alpha$-DG (IIH6C4) and $\alpha$-actin (Sigma) were incubated in $20 \mathrm{mmol} / \mathrm{L}$ Tris (pH 7.4), $150 \mathrm{mmol} / \mathrm{L} \mathrm{NaCl}$, and $0.1 \%$ Tween 20 at 1:2000 dilutions. $\alpha$-DG and $\alpha$-actin antibodies were detected by horseradish peroxidase-goat anti-mouse IgM (Invitrogen) and goat anti-rabbit IgG-horseradish peroxidase conjugate (Bio-Rad), respectively. Blots were developed with electrochemiluminescence (PerkinElmer, Waltham, MA), and the images were exposed and processed by a LAS-4000 imaging system (Fujifilm, Valhalla, NY).

\section{Laminin Binding Assay}

Proteins were transferred to polyvinylidene difluoride membranes and blocked for 1 hour at $4^{\circ} \mathrm{C}$ in laminin overlay buffer $(10 \mathrm{mmol} / \mathrm{L}$ ethanolamine, $140 \mathrm{mmol} / \mathrm{L} \mathrm{NaCl}, 1 \mathrm{mmol} / \mathrm{L}$ $\mathrm{MgCl}_{2}$, and $1 \mathrm{mmol} / \mathrm{L} \mathrm{CaCl} 2, \mathrm{pH} \mathrm{7.4)} \mathrm{containing} \mathrm{5 \%} \mathrm{nonfat}$ dry milk. Membrane was incubated with laminin from Engelbreth-Holm-Swarm murine sarcoma basement membrane (Sigma) for overnight at $4{ }^{\circ} \mathrm{C}$. Anti-laminin antibody (Sigma) was incubated at 1:1500 dilutions. Antibody against laminin was detected by goat anti-rabbit $\mathrm{IgG}$-horseradish peroxidase conjugate (Bio-Rad), and blots were developed with electrochemiluminescence.

\section{RNA Isolation}

RNAs from TA muscles (three or more samples for each group) were isolated using TRIzol reagent (Invitrogen). The A260/ A280 ratio and RNA concentration were determined using NanoDrop ND-2000c (Thermo Scientific, Wilmington, DE). RNA integrity was assessed using the Agilent 2100 Bioanalyzer (Agilent Technologies, Santa Clara, CA). An A260/ A280 ratio in the range of 1.8 to 2.0 and RNA integrity number $>7$ were considered acceptable.

\section{Quantitative RT-PCR}

Total RNAs were reverse transcribed with iScript cDNA Synthesis kit (Bio-Rad). Quantitative RT-PCR was performed on an ABI Prism 7500 Fast Real-Time PCR system using TaqMan Probe-Based Detection (Applied Biosystems, Foster City, CA). The FKRP (HS00748199_S1), LARGE (HS00191000_M1), and DAG1 (HS00189308_M1) gene probes were obtained from Applied Biosystems. Glyceraldehyde-3-phosphate dehydrogenase (Mm99999915_g1) was used as an internal control. All reactions were performed in triplicate. Data were analyzed using RealTime StatMiner version 4.0 (Integromics, Philadelphia, PA).

\section{RNA Array Analysis}

RNA samples were reverse transcribed, amplified, and labeled using 3' IVT Express Kit (Affymetrix Inc., Santa Clara, CA). The resultant labeled complementary RNA was purified and fragmented as per vendor's instructions. The complementary RNA samples together with probe array controls were hybridized onto Affymetrix HT MG-430 PM array strips. Probes for housekeeping genes were used to assess sample integrity. Hybridization, washing, staining, and scanning were performed using Affymetrix GeneAtlas personal microarray system instruments. Affymetrix GeneAtlas instrument control software version 1.0.5.267, was used to analyze microarray image data and to compute intensity values. Affymetrix .CEL files containing raw, probe-level signal intensities were analyzed using Partek Genomics Suite software version 6.6.12.0713 (Partek, St. Louis, MO). Robust multichip averaging was used for background correction, quantile normalization, and probeset summarization with median polish. The statistical difference was calculated by two-way analysis of variance analysis with false-discovery rate. Pathway analysis was performed using Ingenuity Pathway Analysis software version 23814503 (Ingenuity Systems Inc., Redwood City, CA).

\section{Cytokine Assay}

Multiplex cytokine array analysis was performed using the Bio-Plex protein multiarray system, which uses Luminexbased technology. For the current experiments, Bio-Plex Pro Mouse Cytokine 23-plex Assay was used, according to the manufacturer's recommendations (Bio-Rad). Assays are conducted at the Molecular Biology Core Facility, Cannon Research Center (Charlotte, NC).

\section{Results}

Functional Glycosylation of $\alpha$-DG Is Associated with Regenerating Fibers of FKRP P448L $L^{-}$Mutant Muscles

We have previously reported several strains of $F K R P$ mutant mice with three clinically relevant mutations, the common L276I mutation associated with mild LGMD2I, the P448L mutation associated with severe congenital muscular dystrophy, and a nonsense point mutation, E310X. ${ }^{42}$ The muscles of $L 276 I$ mutant express reduced levels of F- $\alpha$-DG in most fibers. The homozygote of P448L mutant without $\mathrm{Neo}^{\mathrm{r}}$ cassette $\left(P 448 \mathrm{~L}^{-}\right)$ lacks $\mathrm{F}-\boldsymbol{\alpha}$-DG in nearly all muscle fibers of skeletal muscles. However, a few fibers $(<2 \%)$ expressing strong F- $\alpha$-DG were detected by immunohistochemistry with the antibody IIH6 in all skeletal muscles (Figure 1A). Most fibers with strong IIH6 positivity were of small caliber, with central nucleation, and frequently appeared as clusters. These fibers, therefore, were likely the newly regenerated as the result of degeneration of the dystrophic muscles. A few fibers with larger calibers were also stained positive with IIH6, but with decreasing intensity. To confirm the relationship between regeneration and IIH6 


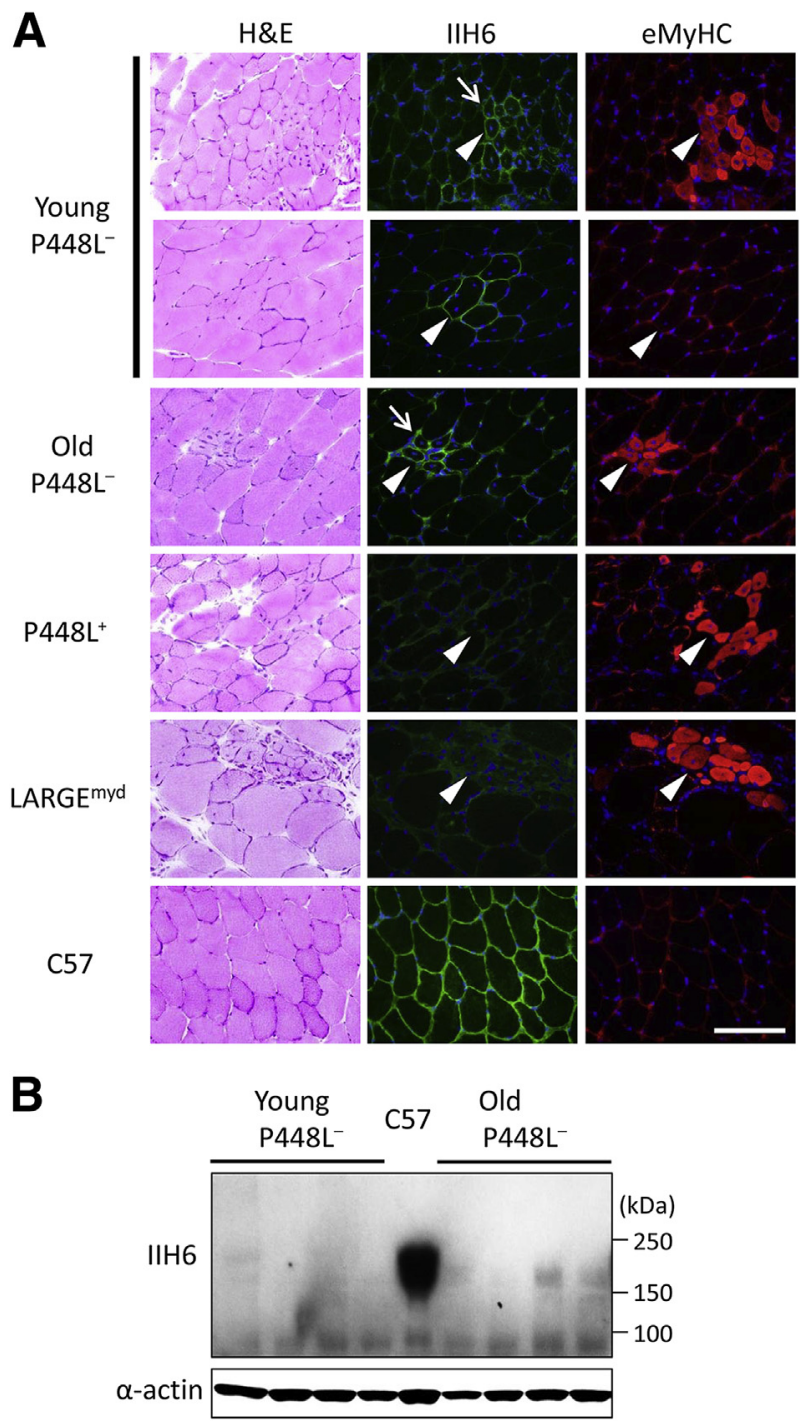

Figure 1 Expression of functionally glycosylated $\alpha$-dystroglycan (F- $\alpha$-DG; IIH6) in non-treated skeletal muscle tissues. A: Immunohistochemical staining of tibialis anterior (TA) muscles from 3- to 6-week-old (young) and

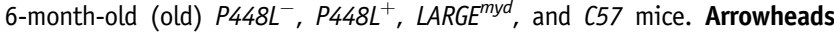
indicate the same fiber in serial sections; arrows indicate the myofibers with $\mathrm{F}-\alpha$-DG in FKRP mutant mice. Cellular nuclei were counterstained with DAPI (blue). B: Western blot analysis of the protein lysate from TA muscle in non-

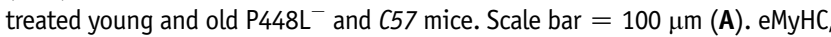
embryonic myosin heavy chain; $\mathrm{H} \& \mathrm{E}$, hematoxylin and eosin.

staining, antibody to eMyHC was used in combination with IIH6 for colocalization. Nearly all small-diameter and neonatal myosin-positive fibers were IIH6 positive in $P 448 L^{-}$mice (Figure 1A). However, IIH6-positive fibers of normal size and lack of eMyHC expression were also observed. Most of these fibers were central nucleated, and signal intensity with IIH6 was generally weaker than that observed in the small regenerating fibers. The limited number of fibers with F- $\alpha$-DG in $P 448 L^{-}$ was indicated by Western blot analysis, showing only a trace amount signal detected with the IIH6 (Figure 1B). These results, therefore, indicate that restoration of F- $\alpha$-DG in the $P 448 L^{-}$is associated largely with muscle regeneration and the early phase of fiber maturation.
Lack of Revertant Fibers in $P 448 L^{+}$and $L A R G E^{m y d}$ Mutant Muscles

To test whether revertant fibers expressing F- $\alpha$-DG are a general feature of dystroglycanopathy, we examined the muscles of the $L A R G E^{\text {myd }}$ and $P 448 L^{+}$mutant mice by immunohistochemistry with the antibody IIH6. All three muscles (cardiac, diaphragm, and TA) of the $L A R G E^{\text {myd }}$ mice were completely devoid of revertant fibers (Figure 1A and Supplemental Figure S1). Skeletal muscles of the P448L ${ }^{+}$ mutant mouse lacked clearly detectable F- $\alpha$-DG, although occasional weak patches of membrane staining were noticed, but such signals were difficult to be distinguished from background with secondary antibody (rabbit anti-mouse Ig) alone. Consistent with immunohistochemistry, Western blots with the same antibody, IIH6, failed to detect convincing band representing $\alpha$-DG in both $L A R G E^{\text {myd }}$ and $P 448 L^{+}$muscles (Figure 2A). The results suggest that the presence of revertant fibers depends on the $L A R G E$ functions. Because both FKRP mutant strains contain the same $P 448 \mathrm{~L}$ mutation, the apparent difference is the level of FKRP expression (Figure 2B). This is consistent with the fact that nearly all of the fibers in L276I mutant mice express $\mathrm{F}-\alpha$-DG at variable levels. Therefore, certain levels of function from the mutant FKRP appeared to be required for the F- $\alpha$-DG in the regenerating fibers.

\section{Functional Glycosylation of $\alpha-D G$ in Regenerating Muscle Fibers after NTX-Induced Damage}

To confirm that F- $\alpha-\mathrm{DG}$ in revertant fibers of the $P 448 L^{-}$ mutant mice was directly related to muscle regeneration, we examined the regenerating TA muscles of the mutant mice at 2 , $4,7,14$, and 28 days after the single injection of NTX. To assess the impact of NTX in the muscle and regenerative potency, we counted numbers of regenerating fibers with eMyHC-positive staining in the treated muscles (Supplemental Figure S2). NTX geometrically caused muscle degeneration to a wide area in young mice regardless of strains. Immunohistochemistry demonstrated strong membrane staining with IIH6 antibody in the regenerating fibers with small caliber and central nucleation at 4 days after injection (Figure 3A). Most of IIH6-positive fibers were, as expected, found in groups surrounding the needle tract of the injection sites. The nature of regenerating fibers was confirmed by eMyHC expression. Surprisingly, the signal intensity with the IIH6 antibody in the regenerating $P 448 L^{-}$muscles was similar to that detected in regenerating normal muscle fibers at both 4 and 7 days after NTX treatment. The regenerating fibers expressing eMyHC expression remained strongly positive with the IIH6 antibody up to 14 days after injection. IIH6 staining became weaker, yet remained detectable, in the most fibers of the damaged areas 28 days after treatment, although these fibers were negative to the $\mathrm{MyHC}$. A few IIH6-positive fibers with normal size and without eMyHC expression and central nucleation were also observed (Supplemental Figure S3). 


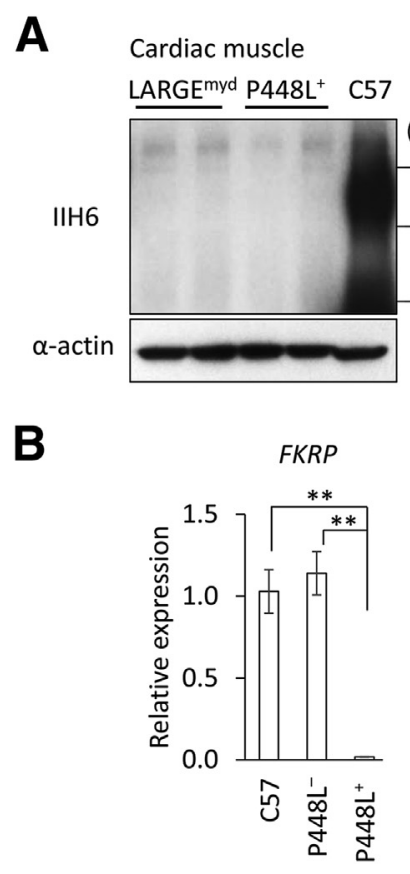

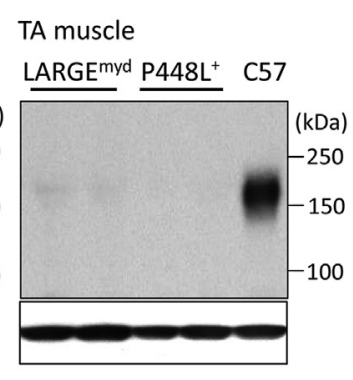

LARGE

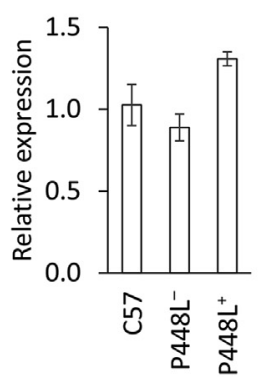

DAG1

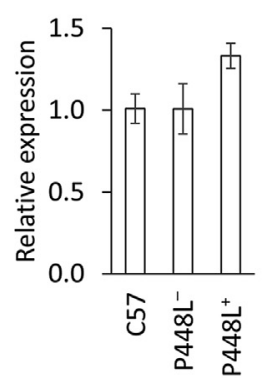

Figure 2 Expression of functionally glycosylated $\alpha$-dystroglycan ( $F-\alpha-D G$ ) and fukutin-related protein (FKRP). A: Western blot analysis confirms lack of $F-\alpha-D G$ in cardiac muscle, diaphragm, and tibialis anterior (TA) muscles from LARGE ${ }^{\text {myd }}$ and $\mathrm{P}_{448 \mathrm{~L}^{+}}$mice. B: Quantitative RT-PCR of FRKP, $\angle A R G E$, and DAG1 in 1-month-old mice. Data are given as means \pm SEM. $N=3$ per group. $* * P<0.01$.
To assess whether the regeneration and F- $\alpha$-DG expression in the $P 448 L^{-}$muscles are the results specific to the NTX-induced damage, we also examined the impact of strongly positivecharged $25 \mathrm{kDa}$ PEI-induced muscle degeneration and regeneration on the expression of $\mathrm{F}-\alpha-\mathrm{DG}$ in the $\mathrm{P}_{4} 48 \mathrm{~L}^{-}$mice. PEI with the current dose induced damage limited to smaller area than NTX (Supplemental Figure S4). However, all regenerating fibers positive with eMyHC expression were also detected with strong signal by the IIH6 antibody and maintained the same positive relationship between the two antibodies up to day 14 after treatment. Similarly, by day 28 , large fibers with nearly normal sizes in the area of injection sites were still seen with weak IIH6 signal. The levels of F- $\alpha$-DG were also examined by Western blot analysis in the isolated areas containing a large proportion of regenerating fiber clusters (Figure 3, B and C). Although native $P 448 L^{-}$muscle only showed a trace amount of IIH6 signal (Figure 1B), PEI and NTX treatment restored IIH6 expression into the level that was approximately consistent with an extent of regenerating fibers in the $\mathrm{P}_{448 \mathrm{~L}^{-}}$. The glycosylated $\alpha$-DG in regenerating fibers was also able to bind to the laminin, as shown by the binding assay (Figure 3D). These results, therefore, confirm that restoration of $\mathrm{F}-\alpha-\mathrm{DG}$ in the FKRP mutant muscles is closely associated with muscle regeneration, and the levels gradually decline with the maturation of the muscle fibers. The levels of F- $\alpha$-DG in the muscles treated with NTX were similar to that in the untreated muscles of the C57 mice (Supplemental Figure S5).

Functional Glycosylation of $\alpha$-DG in the Regenerating Fibers of 6-Month-Old $\mathrm{P}_{448 \mathrm{~L}^{-}}$Mice

To dissect if aging could affect restoration of F- $\alpha$-DG in $P 448 L^{-}$mice, we performed the i.m. injections of NTX into 6-month-old $P 448 L^{-}$mice and again examined the injected TA muscles at 2, 4, 7, 14, and 28 days after treatment. Similar to the young $P 448 L^{-}$group, central nuclear fibers with a small diameter and expressing eMyHC were also strongly stained with IIH6 between 4 and 14 days (Supplemental Figure S6). There were no significant differences in the overall pattern of IIH6 staining at the five time points between the young and old $P 448 L^{-}$groups. However, there was one noticeable variation when this was compared with the PEI-treated muscles. There was a delay in the appearance of newly formed small-caliber myofibers when the damage was induced by the PEI, and this was coincident with the delay in the detection of IIH6 staining. The strongest F- $\alpha$-DG was detected by day 14 and remained at detectable levels by day 28 . The levels of F- $\alpha$-DG were confirmed by immunoblotting using IIH6 antibody (Figure 4, A and B). PEI-treated muscle demonstrated the intensity of signals for F- $\alpha$-DG almost the same as normal C57 muscle 14 days after treatment and remained so at 28 days. This might be related to a slow regeneration and fiber maturation process in older muscles. ${ }^{45,46}$ These results indicate that old $P 448 L^{-}$muscle could temporally restore the F- $\alpha-\mathrm{DG}$ to similar levels as normal C57 after PEI and NTX treatment.

\section{Regeneration in the LARGE ${ }^{\text {myd }}$ and FKRP P $448 L^{+}$Mutant Mice Is Unable to Restore Functional Glycosylation of $\alpha-D G$}

To investigate if $\mathrm{F}-\alpha-\mathrm{DG}$ could be restored to the regenerating muscle fibers of the $P 448 L^{+}$mice, the same procedure was performed to the TA muscles, and the injected muscles were examined by immunohistochemistry with the IIH6 at 4 and 14 days after the local injection. Although the local injection 
A
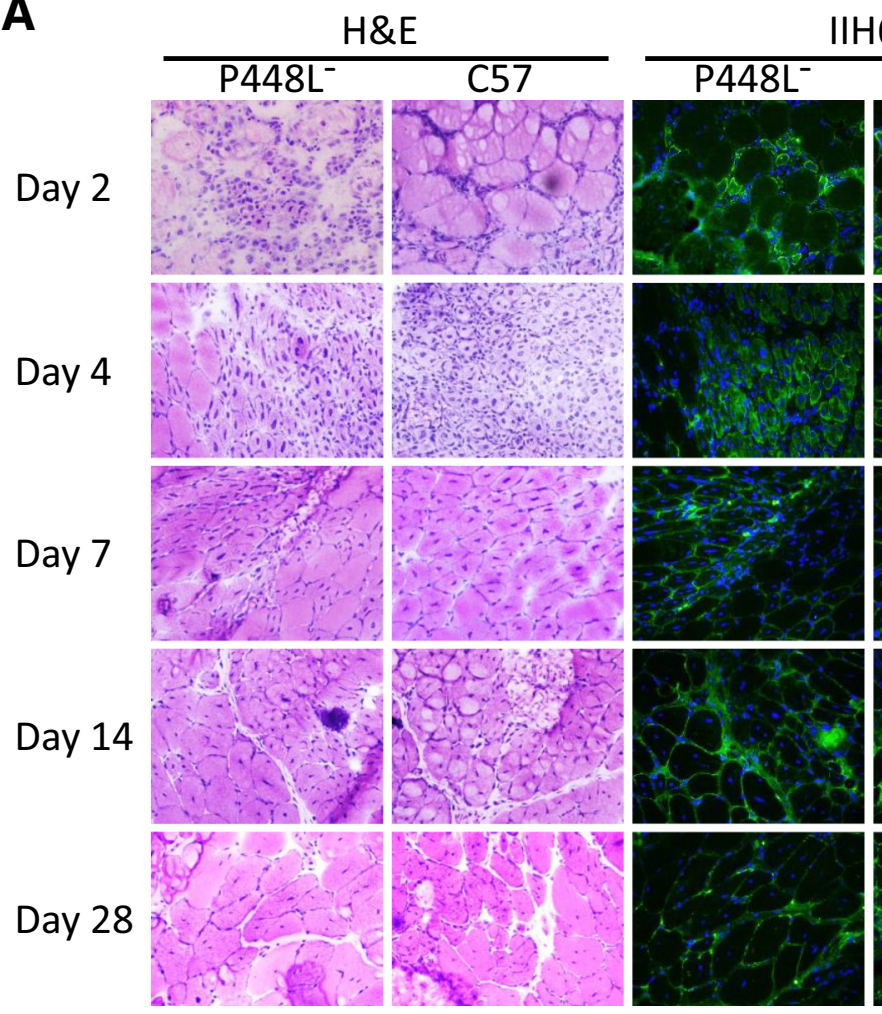

IIH6
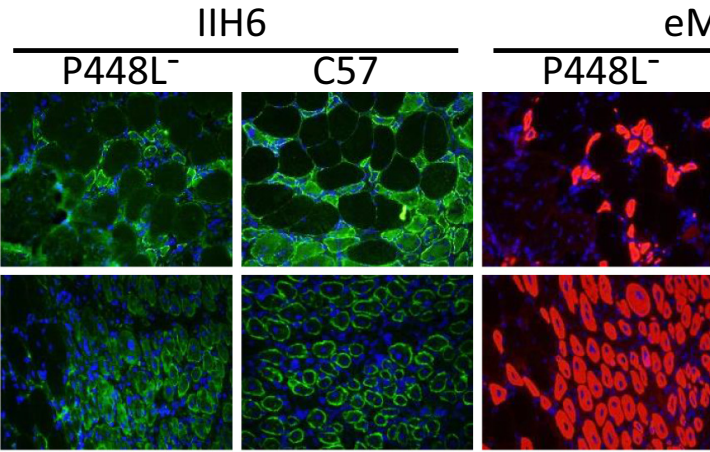

eMyHC
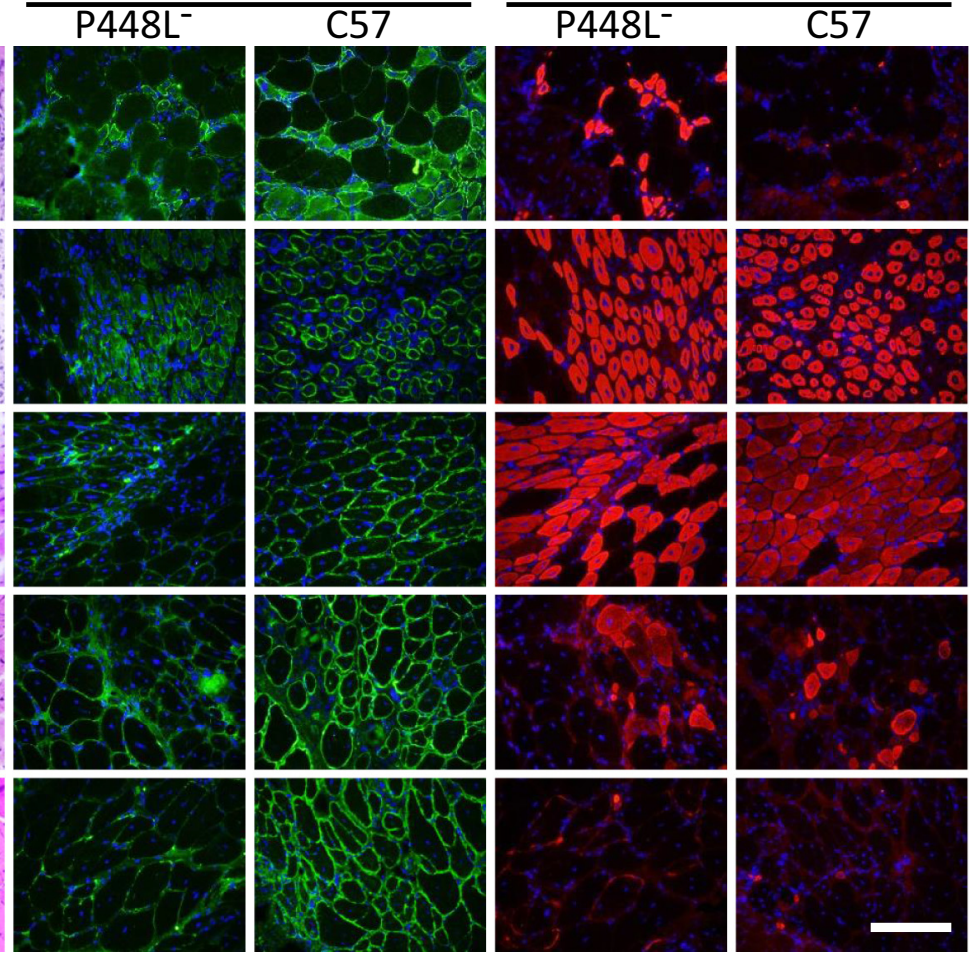

B
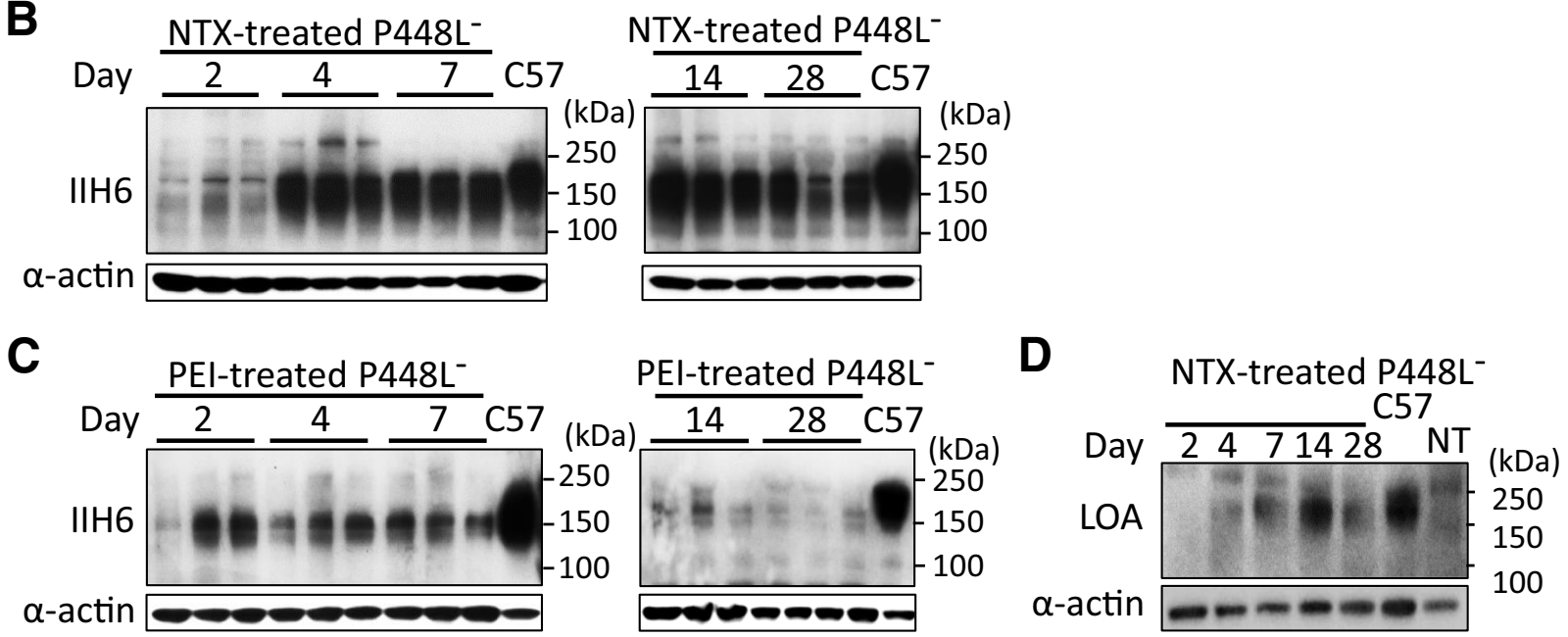

Figure 3 Expression of functionally glycosylated $\alpha$-dystroglycan (F- $\alpha$-DG) in notexin (NTX)-treated muscles from 3- to 6-week-old $P 448 L^{-}$and $C 57$ mice at 2, 4, 7,14 , and 28 days after treatment. A: Hematoxylin and eosin (H\&E) staining and immunohistochemical staining of F- $\alpha$-DG and embryonic myosin heavy chain (eMyHC). Cellular nuclei are counterstained with DAPI (blue). Western blot analysis of NTX-treated (B) and polyethylenimine (PEI)-treated (C) muscles. D: Laminin overlay assay (LOA) using NTX-treated muscles. $\alpha$-Actin was used as controls. Scale bar $=100 \mu \mathrm{m}$. NT, non-treated 3- to 6-week-old P448L ${ }^{-}$.

induced a similar degree of eMyHC-positive fibers with a small diameter and central nucleation (Figure 5A), no clearly positive signals for $\mathrm{F}-\alpha-\mathrm{DG}$ were detected in these regenerating fibers at both time points. This result further confirmed the importance of levels of mutant FKRP protein for the restoration of F- $\alpha$-DG.

We also examined $L A R G E^{\text {myd }}$ muscle, which completely lacks detectable F- $\alpha$-DG without induced regeneration. ${ }^{47}$ Four days after the local injection of NTX, muscle regeneration was evident and the small-caliber and central nucleated fibers were eMyHC positive (Figure 5B). However, similar to the muscles from $\mathrm{P}_{448 \mathrm{~L}^{+}}$mice, no signal for $\mathrm{F}-\alpha-\mathrm{DG}$ was detected in any of the regenerating fibers at any time point after treatment. This lack of F- $\alpha$-DG in dystrophic muscles was also confirmed by Western blot analysis (Figure 5, C and D).

RNA Array Analysis of the $\mathrm{P}_{448 \mathrm{~L}^{-}}$Muscle after Induced Damage

To probe the potential factors involved in the restoration of functional glycosylation of regenerating fibers, RNA array 


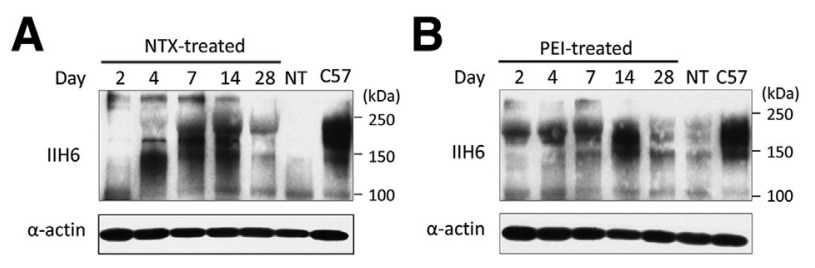

Figure 4 Expression of functionally glycosylated $\alpha$-dystroglycan in muscles from 6-month-old $\mathrm{P}_{448 \mathrm{~L}^{-}}$mice treated with notexin (NTX) and polyethylenimine (PEI). Western blot analysis of NTX-treated (A) and PEI-treated (B) muscles. Numbers at the top of the lanes indicate the days after the initial injection. $\alpha$-Actin was used as controls. (57, muscles from

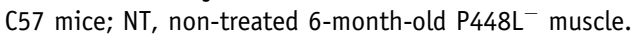

analysis was performed to compare the expression profile of the regenerating muscles of $P 448 L^{-}$mice after injury to the muscles without treatment, with focus on glycosylation-associated genes (Table 1 and Supplemental Table S1) (http://www.ncbi.nlm.nih. gov/geo; Accession number GSE67032). ${ }^{40,48}$ Sixteen glycosylation-associated genes in the treated muscle were upregulated by day 2 after NTX treatment, but only four genes, Alg5, $\beta 4$ galt1, Ext1, and Tmem 165, remained up-regulated by day 4. Gxylt2, St3gal4, and Unc50 showed up-regulation only at day 4. It is interesting that no genes showed significant changes 14 days after NTX treatment.

Expression of F- $\alpha$-DG was at nearly the highest levels at day 14 and remained detectable at day 28 after NTX treatment, as demonstrated by IIH6 antibody and laminin binding (Figure 3, $\mathrm{C}$ and $\mathrm{D}$ ). It is, therefore, unlikely that the selected genes contribute significantly to the restoration of F- $\alpha$-DG in the FKRP mutant mouse in the regenerating fibers. This was consistent with the RNA array results from PEI-treated muscles of $P 448 L^{-}$mice, which also did not exhibit up-regulation of these genes. It remains possible that the effect of these genes could persist considerably longer than their mRNA products. Significant difference in gene expression of the PEI-treated muscles was only recorded for the following two genes, mannose-P-dolichol utilization defect 1 (Mpdul) and DOT1like, histone $\mathrm{H} 3$ methyltransferase (Dotll), with -1.81 - and -1.55-fold changes $(P<0.005)$, respectively, compared with NTX-treated muscle at 2 days. No increase in expression of LARGE and FKRP was identified at any time point during the regeneration after NTX treatment, suggesting that up-regulation of the two genes is unlikely involved. Thus, alteration in other yet unknown factors is responsible for the synthesis of F- $\alpha$-DG with the functionally defected FKRP in the regenerating fibers.

\section{Inflammatory Factor Profile in Regenerating Muscles after Damage}

One clear difference between the two-agent treatment is that PEI-treated muscles showed considerably higher levels of F- $\alpha$ DG at day 2, whereas NTX-treated muscles expressed significantly elevated $\mathrm{F}-\alpha-\mathrm{DG}$ from day 4 and onward (Figure 6). Muscular damage (necrotic fibers) and mononuclear cell infiltration were more obvious with PEI treatment than NTX treatment at day 2. The number of regenerating fibers with the PEI injury was, however, no higher than that with the NTX injury. These findings suggest that some of the F- $\alpha$ DG might originate from the pre-existing muscle fibers and be induced by inflammatory-related factors. We, therefore, examined the protein expression profile of a group of cytokines within the injured muscles.

The levels of most inflammatory factors (IL- $1 \beta$, IL-3, IL-5, IL-6, IL-10, IL-12, and interferon- $\gamma$ ) were higher (although statistically not significant) in PEI-treated muscles than those in NTX-treated muscles at both 2 and 7 days, supporting the histological observation that PEI causes more severe and earlier inflammation in $P 448 L^{-}$mice (Figure 6). PEI-treated $\mathrm{P}_{448 \mathrm{~L}^{-}}$showed a significantly higher concentration of macrophage inflammatory protein (MIP)-1 $\beta$ and regulated on activation normal T-cell expressed and secreted (RANTES), but lower levels of IL-1a and IL-2 at day 2 when compared with NTX-treatment muscles. The levels of MIP-1 $\beta$ and RANTES remained higher, whereas those of IL-1a and IL-2 reversed to higher at day 7 in PEI-treated muscles compared with those in NTX-treated muscles. Other factors showing a significant difference between PEI- and NTX-treated muscles at day 7 included IL-3, IL-4, IL-12 (p40), IL-12 (p70), IL-13, granulocyte-specific colony-stimulating factor, interferon- $\gamma$, and MIP-1 $\beta$ (Figure 6). In the NTX-treated normal C57 muscles, the levels of most inflammatory factors were highest at day 2, but quickly became lower when compared with the $\mathrm{P}_{448 \mathrm{~L}^{-}}$muscles treated with either of the reagents (Figure 6).

The persistent higher levels of the factors in the $P 448 L^{-}$ muscles likely reflect the continuing cycles of the degeneration in the dystrophic mice. Although the current data are insufficient to determine which factor(s) might be involved in the restoration of F- $\alpha$-DG, the persistent higher levels of many inflammatory factors in PEI-treated muscle, especially the significance of MIP-1 $\beta$ and RANTES in the restoration of $\mathrm{F}-\alpha-\mathrm{DG}$ of $F K R P$ mutant muscles, needs to be explored.

\section{Discussion}

\section{Revertant Fiber Is Associated with Regeneration}

Mutations of $F K R P$ are associated with hypo or lack of $\mathrm{F}-\alpha-$ DG. Yet, a small percentage of muscle fibers in the FKRP $P 448 L$ mutant mice associated with severe disease phenotype express clearly detected F- $\alpha$-DG by immunohistochemistry, with signal intensity similar to that in normal muscle fibers. We call these fibers revertant fibers, which have been reported in both human and mouse models of FKRP mutant. ${ }^{42,49-51}$ These revertant fibers often exist as groups with small caliber, and some of them co-express eMyHC, suggesting that they are associated with muscle regeneration. ${ }^{52}$ However, fibers of normal size without central nucleation can also be found with clear membrane signals for F- $\alpha-\mathrm{DG}$, raising question that factors unrelated to muscle regeneration could also be involved. By using the FKRP P448L mutant mouse models together with normal controls, we now confirmed that revertant expression of F- $\alpha$-DG is closely related to the regeneration. Although myoblasts express 
A

A
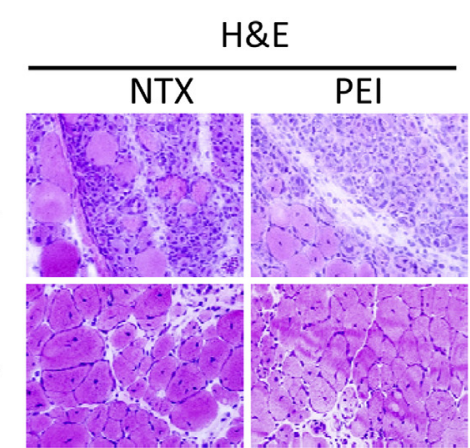

Day 14

B

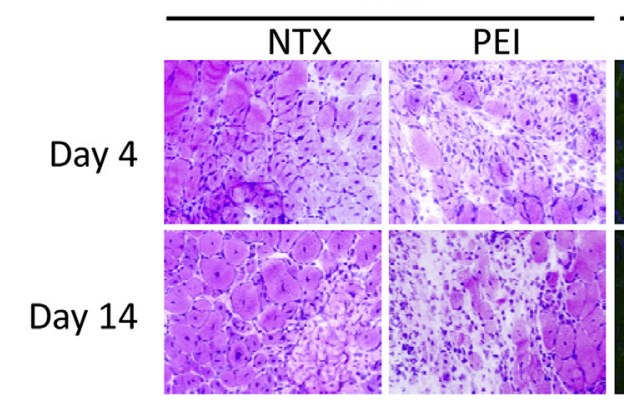

H\&E

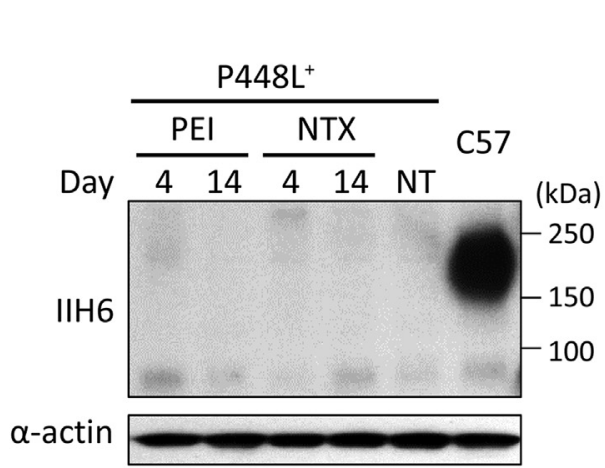

IIH6

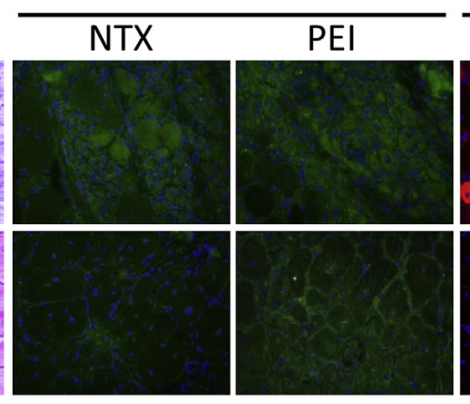

IIH6
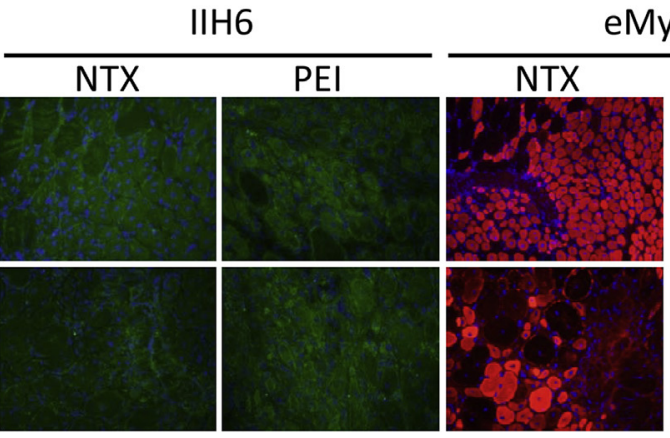

eMyHC

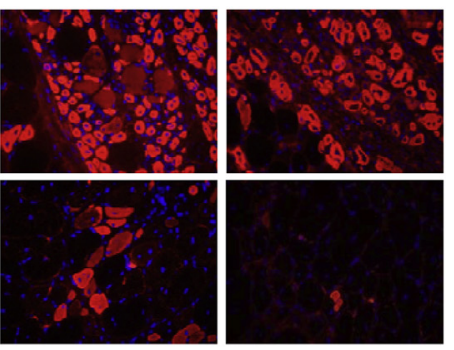

D

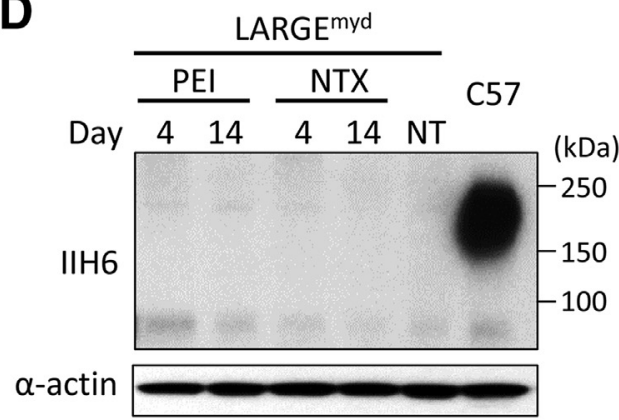

Figure 5 Lack of functionally glycosylated $\alpha$-dystroglycan (F- $\alpha-D G)$ expression in muscles from $P 448 L^{+}(\mathbf{A})$ and $L A R G E^{\text {myd }}(\mathbf{B})$ mice. Hematoxylin and eosin (H\&E) staining and immunohistochemical staining of notexin (NTX) - and polyethylenimine (PEI)-treated tibialis anterior muscles with IIH6 and embryonic myosin heavy chain (eMyHC) antibodies. Serial sections were used for the two stainings. No IIH6 signals are detected in eMyHC-positive regenerating myofibers with a small diameter. Nuclei were counterstained with DAPI (blue). Western blot analysis of PEI- and NTX-treated muscles from $P 448 L^{+}$(C) and $\operatorname{LARGE}^{\text {myd }}$ (D) mice. Numbers at the top of the lanes indicate the days after the initial injection. $\alpha$-Actin was used as controls. Scale bar $=100 \mu \mathrm{m}(\mathbf{A}$ and $\mathbf{B})$. C57, muscles from C57 mice; NT, non-treated mutant mice.

barely detectable F- $\alpha$-DG, the newly regenerated myotubes of the $P 448 L^{-}$mouse muscles express strong F- $\alpha$-DG up to approximately 14 days, followed by a gradual decrease in signal intensity in the maturing fibers, with increasing diameter and loss of eMyHC expression. F- $\alpha$-DG remains detectable by 28 days, albeit with decreasing signal intensity. F- $\alpha$-DG in fibers with normal size without central nucleation was also observed, suggesting that the expression could maintain $>28$ days, although this cannot be verified because regeneration continues in the FKRP mutant mouse muscles.

\section{Critical Role of FKRP and LARGE for the Revertant Expression of $F-\alpha-D G$}

The mechanism responsible for the reversion of F- $\alpha$-DG is not clear. With the comparison to the available mouse models of FKRP mutations and $L A R G E^{\text {myd }}$ mice, it is clear that the reversion event remains LARGE and FKRP dependent, because no or only trace amount of revertant F- $\alpha$-DG was detected in the $L A R G E^{\text {myd }}$ muscles and the muscles of FKRP $P 448 L^{+}$mouse, respectively, during the entire regeneration period after both NTX and PEI treatment (Figure 5C). These results provide important indication that mutant FKRP, such as P448L associated with severe disease phenotype in the clinic, can still be sufficient for the regenerating muscle fibers to produce near normal levels of F- $\alpha$-DG. However, the P448L FKRP mutant protein is insufficient in the mature fibers for the production of F- $\alpha$-DG. This is consistent with the observation in the clinic that most patients with FKRP mutations have variable numbers of revertant fibers, which are also eMyHC positive. $^{49,53}$ 
Table 1 Expression Changes of Potential and Confirmed Glycosylation-Related Genes in the NTX-Treated Muscles from P448L Mice

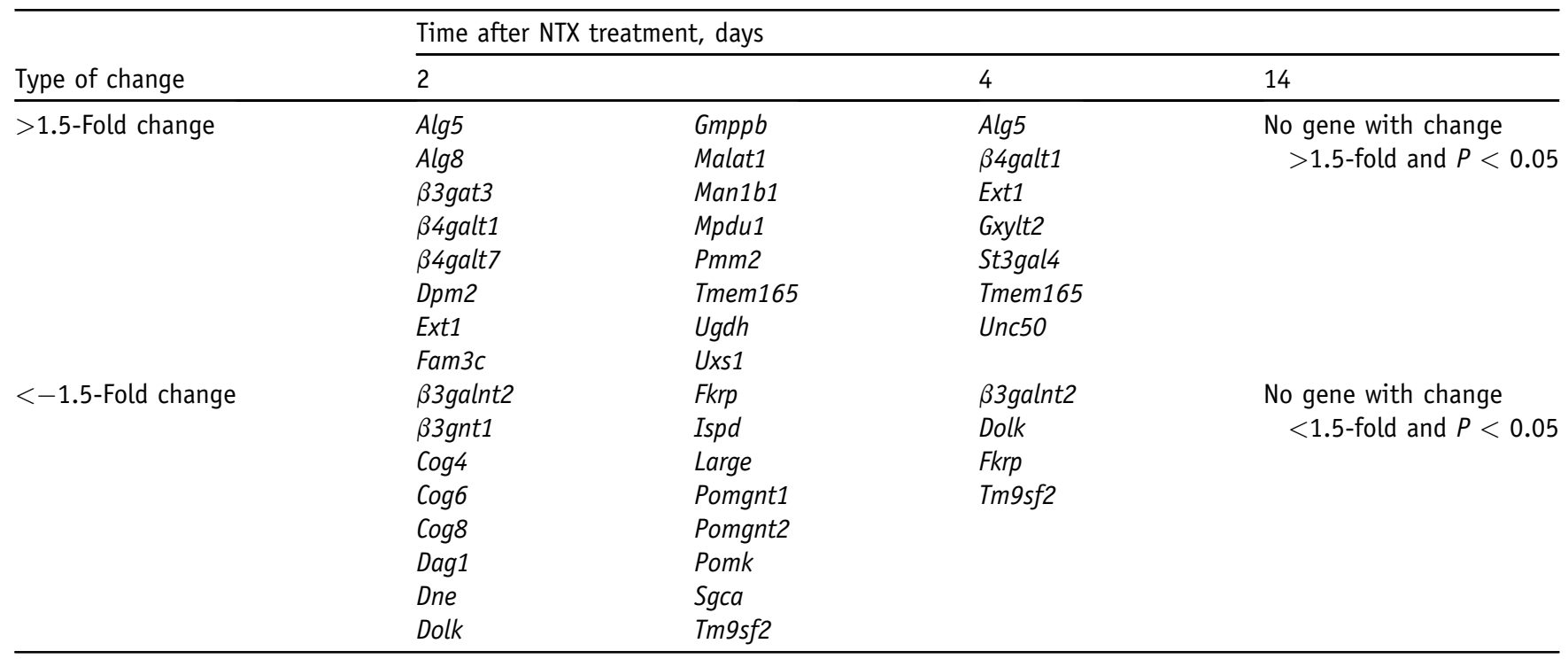

Only the genes with $>1.5$-fold change and $P<0.05$, or with $<-1.5$-fold change and $P<0.05$, compared with the muscle from non-treated P448L- mice are listed.

NTX, notexin.

Our previous study of several FKRP mutant mice clearly showed the importance of the nature of FKRP mutation on the levels of F- $\alpha$-DG. ${ }^{42}$ Muscles from the mild L276I mutant mice retain the capacity to produce reduced levels of F- $\alpha$-DG in most fibers, and all regenerating fibers in the $P 448 L^{-}$mutant were strongly positive with the IIH6 staining. Comparison between the $\mathrm{P}_{448 \mathrm{~L}^{-}}$and $P 448 \mathrm{~L}^{+}$ suggests that factors other than the nature of mutation can also be important on F- $\alpha$-DG. Both P448L strains were backcrossed to $C 57 B L / 6$ background for nine generations, and one major difference between them was the levels of the mutant FKRP expression because of the presence or absence of $\mathrm{Neo}^{\mathrm{r}}$ cassette (Figure 2B). For this study, we could not determine the protein levels of the endogenous FKRP in the mutant muscles, because of the lack of high-affinity antibody and understanding of how the FKRP protein interacts with other elements. The presence of the $\mathrm{Neo}^{\mathrm{r}}$ cassette may well reduce the FKRP protein level at both transcription and translation levels, leading to a more severe phenotype and lack of clear reversion in F- $\alpha$-DG in the $P 448 L^{+}$mice. Thus, a threshold amount of specific mutant FKRP is required to achieve significant reversion of F- $\alpha$-DG. However, disruption of other gene expression by the $\mathrm{Neo}^{\mathrm{r}}$ cassette cannot be excluded.

To investigate the factors other than FKRP compensating for the reduced function of FKRP in the reversion of F- $\alpha-\mathrm{DG}$, we conducted microarray studies of the regeneration process in normal and P448L mutant mice, with focus on the genes known to be involved in the glycosylation of $\alpha$-DG. The data show no significant changes in the expression of FKRP and LARGE during the entire regeneration process, during which levels of F- $\alpha$-DG change dramatically (Supplemental Table S1) (http://www.ncbi.nlm.nih.gov/geo;
Accession number GSE67032). LARGE was, in fact, downregulated at day 2 after muscle damage and became stable by day 4 . The general smaller size of F- $\alpha$-DG in the regenerating muscle is also in contrast with the larger MW of F- $\alpha-\mathrm{DG}$, with LARGE overexpression in transfection studies. ${ }^{54}$ Similarly, analyzing a large set of microarray data from regenerating skeletal muscles deposited by Children's National Medical Center (Washington, DC) (http://www.ncbi.nlm.nih. gov/geo; Accession number GSE469) also showed no increase in expression of $L A R G E$. In fact, the levels of $L A R G E$ decreased in the first 4 days and then remained stable up to 40 days during cardiotoxin-induced regeneration. Only two genes, Mpdul and Dot 1 , were found to be differentially expressed at day 2 between the PEI- and NTX-treated muscles in our study. Mpdu1 is a membrane protein that localizes in the endoplasmic reticulum and is essential for dolichol-linked oligosaccharide biosynthesis. ${ }^{55,56}$ The mutations of MPDU cause congenital disorder of glycosylation 1f in humans. ${ }^{57,58}$ Dot1l catalyzes the methylation of histone H3 lysine 79 and plays an important role in the activation and maintenance of gene transcription. ${ }^{59}$ These results indicate that factors other than FKRP and LARGE could be responsible for the reversion.

\section{Other Potential Factors in the Revertant Expression of $\mathrm{F}-\alpha-\mathrm{DG}$}

Our results also reveal that, although the levels of F- $\alpha$-DG become greatly reduced by 28 days after the initial damage, the IIH6 signals by Western blot analysis remain higher than background, suggesting that the reversion effect related to regeneration continues. Interestingly, myofibers surrounding the damaged area in PEI-treated muscles were 

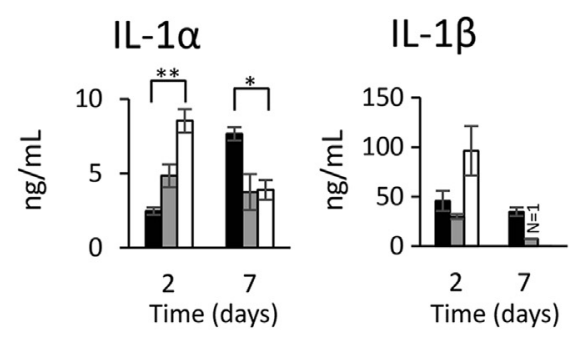

IL-5

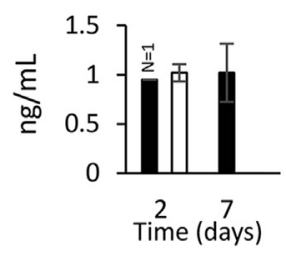

IL-13

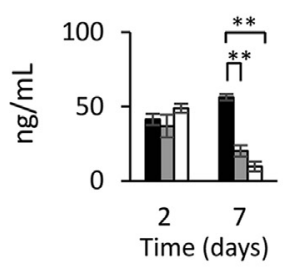

KC

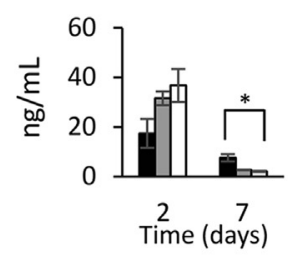

IL-6

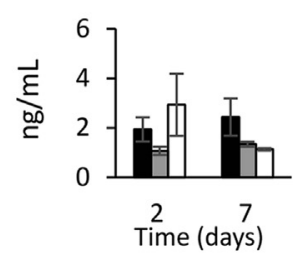

IL-17A

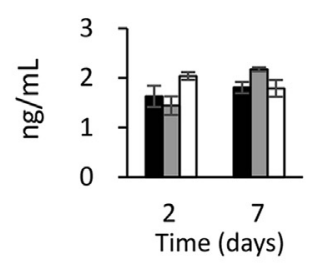

MCP-1

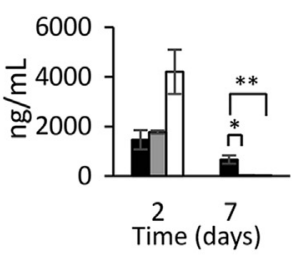

IL-2

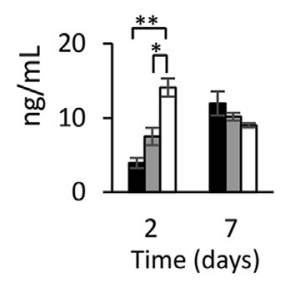

IL-10

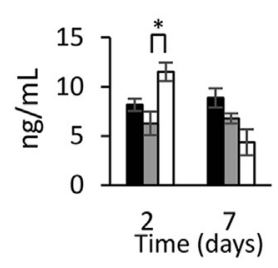

G-CSF

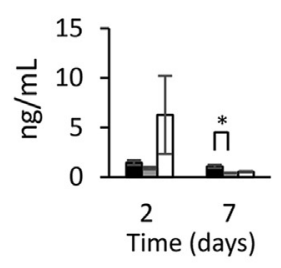

MIP-1 $\alpha$

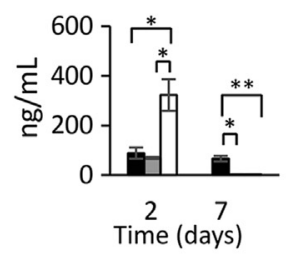

IL-3

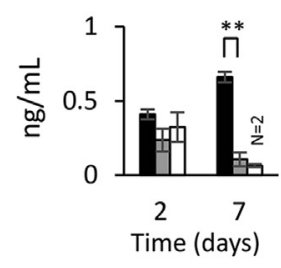

IL-12(p40)

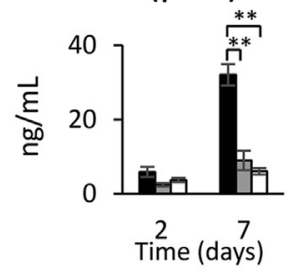

GM-CSF

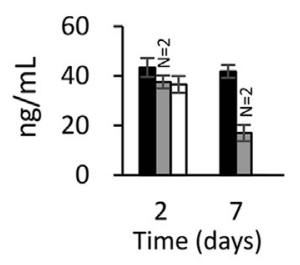

MIP-1 $\beta$

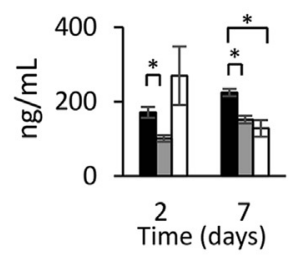

IL-4

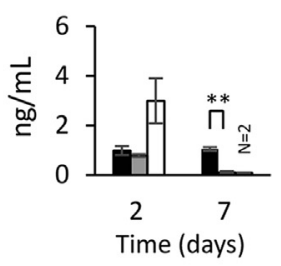

IL-12(p70)

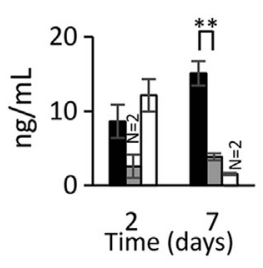

IFN- $\gamma$

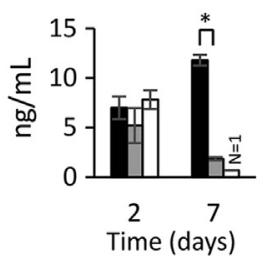

RANTES

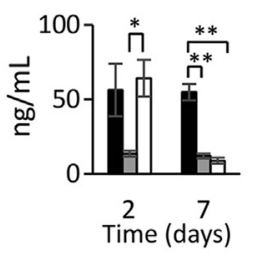

PEI-Treated P448L'

NTX-Treated P448L'

NTX-Treated C57

Figure 6 Quantitative analysis of cytokines, chemokines, and growth factors in tibialis anterior muscles 2 and 7 days after polyethylenimine (PEI) and notexin (NTX) treatment in $P 448 L^{-}$mice and NTX treatment in C57 mice (3 to 6 weeks of age). Data are given as means \pm SEM. $N=3$ per group. ${ }^{*} P<0.05$, ${ }^{* *} P<0.01$. G-CSF, granulocyte-specific colony-stimulating factor; GM-CSF, granulocyte-macrophage CSF; IFN, interferon; KC, keratinocyte chemoattractant; MCP, monocyte chemoattractant protein; MIP, macrophage inflammatory protein; RANTES, regulated on activation normal T-cell expressed and secreted.

observed expressing IIH6 signal, although at lower levels at day 2 after treatment (Supplemental Figure S3). The clearly elevated levels of F- $\alpha$-DG at day 2 were also confirmed in both young and old mice by Western blot analyses. Regenerating myotubes were usually only clearly identified by day 4 in muscles after damage in both the PEI- and NTXtreated mice (Figure 3, B and C).

Because the levels of the F- $\alpha$-DG did not increase in the NTX-treated muscle at day 2 and there was no difference in the regeneration process in histology between the two treatments, it is unlikely that the source of the F- $\alpha$-DG is from the prefusion myogenic cells. In vitro cell culture results further support the view because myoblasts do not express a significant amount of F- $\alpha$-DG. ${ }^{60}$ Therefore, it is likely that $\mathrm{F}-\alpha$-DG 2 days after PEI treatment may have arisen from the fibers surrounding the PEI-induced damage site, as immunostaining indicated. One clear difference between NTX and PEI treatment is that the latter induces higher levels of inflammatory reaction. ${ }^{61}$ It is, therefore, possible that factors involved in the inflammatory process can also affect the glycosylation of $\alpha$-DG, leading to enhanced $F-\alpha-D G$ in mature muscle fibers. Our initial protein profiling did show some differential expression between the two treatments. It will be interesting to assess the effect of individual factors in the process of glycosylation of $\alpha$-DG.

\section{Molecular Size of F- $\alpha-D G$ with Age and Regeneration Process}

One interesting piece of data from this study is the variability of the molecular sizes of glycosylated $\alpha$-DG detected 
by the IIH6. In young $P 448 L^{-}$mutant mice, the F- $\alpha$-DG from both PEI- and NTX-treated muscles at all time points of the regeneration process has the MW slightly, but clearly smaller, than that from the muscles of the age-matched normal mice (Figure 3, B and C). However, in the older mice, the F- $\alpha$-DG from PEI-treated muscles had similar MW as the age-matched normal control, whereas F- $\alpha$-DG in the NTX-treated muscle showed a clearly lower MW at 4 days and then increased to the normal size of control sample (Figure 4, A and B). The reasons for the variation in size of F- $\alpha$-DG after NTX treatment are not clear. NTX is a presynaptically active toxic phospholipase and acts to cause the depletion of transmitter from the motor neurons and damage motor nerve terminal when injected intramuscularly. ${ }^{62,63}$ It has been reported that $\alpha$-DG showed a reduced size after denervation in skeletal muscle. ${ }^{64}$ It is, therefore, possible that the initial reduced MW of $\alpha$-DG after NTX injection is partly related to the NTX-induced denervation effect. It will also be interesting to investigate whether the nature of glycosylation of $\alpha$-DG is fiber maturation and developmentally regulated.

\section{Acknowledgments}

We thank Traci Williamson, Kim Mihalko, Amber Smith, Tracy Walling, Hiral Amin, Amanda Simmons, Judy Parsons, and Nury Steuerwald (Cannon Research Center) for their technical help and Caren Anderson for editing.

\section{Supplemental Data}

Supplemental material for this article can be found at http://dx.doi.org/10.1016/j.ajpath.2015.03.017.

\section{References}

1. Ervasti JM, Campbell KP: Membrane organization of the dystrophinglycoprotein complex. Cell 1991, 66:1121-1131

2. Ervasti JM, Campbell KP: A role for the dystrophin-glycoprotein complex as a transmembrane linker between laminin and actin. J Cell Biol 1993, 122:809-823

3. Kanagawa M, Toda T: The genetic and molecular basis of muscular dystrophy: roles of cell-matrix linkage in the pathogenesis. J Hum Genet 2006, 51:915-926

4. Ervasti JM, Ohlendieck K, Kahl SD, Gaver MG, Campbell KP: Deficiency of a glycoprotein component of the dystrophin complex in dystrophic muscle. Nature 1990, 345:315-319

5. Yoshida M, Ozawa E: Glycoprotein complex anchoring dystrophin to sarcolemma. J Biochem 1990, 108:748-752

6. Ibraghimov-Beskrovnaya O, Ervasti JM, Leveille CJ, Sernett SW, Campbell KP: Primary structure of dystrophin-associated glycoproteins linking dystrophin to the extracellular matrix. Nature 1992, 355:696-702

7. Campanelli JT, Roberds SL, Campbell KP, Scheller RH: A role for dystrophin-associated glycoproteins and utrophin in agrin-induced AChR clustering. Cell 1994, 77:663-674

8. Gee SH, Montanaro F, Lindenbaum MH, Carbonetto S: Dystroglycanalpha, a dystrophin-associated glycoprotein, is a functional agrin receptor. Cell 1994, 77:675-686
9. Brown SC, Fassati A, Popplewell L, Page AM, Henry MD, Campbell KP, Dickson G: Dystrophic phenotype induced in vitro by antibody blockade of muscle alpha-dystroglycan-laminin interaction. J Cell Sci 1999, 112(Pt 2):209-216

10. Montanaro FM, Lindenbaum M, Carbonetto S: alpha-Dystroglycan is a laminin receptor involved in extracellular matrix assembly on myotubes and muscle cell viability. J Cell Biol 1999, 145:1325-1340

11. Talts JF, Andac Z, Gohring W, Brancaccio A, Timpl R: Binding of the $\mathrm{G}$ domains of laminin alpha1 and alpha2 chains and perlecan to heparin, sulfatides, alpha-dystroglycan and several extracellular matrix proteins. EMBO J 1999, 18:863-870

12. Suqita S, Saito SF, Tang J, Satz J, Campbell KP, Sudhof TC: A stoichiometric complex of neurexins and dystroglycan in brain. J Cell Biol 2001, 154:435-445

13. Sato S, Omori Y, Katoh K, Konko M, Kanagawa M, Miyata K, Funabiki K, Koyasu T, Kauimura N, Miyoshi T, Sawai H, Kobayashi K, Tani A, Toda T, Usukura J, Tano Y, Fujikado T, Furukawa T: Pikachurin, a dystroglycan ligand, is essential for photoreceptor ribbon synapse formation. Nat Neurosci 2008, 11: 923-931

14. Brancaccio A, Schulthess T, Gesemann M, Engel J: Electron microscopic evidence for a mucin-like region in chick muscle alphadystroglycan. FEBS Lett 1995, 368:139-142

15. Michele DE, Barresi R, Kanagawa M, Saito F, Cohn RD, Satz JS, Dollar J, Nishino I, Kelley RI, Somer H, Straub V, Matthews KD, Moore SA, Campbell KP: Post-translational disruption of dystroglycanligand interactions in congenital muscular dystrophies. Nature 2002, 418:417-422

16. Moore SA, Saito F, Chen J, Michele DE, Henry MD, Messing A, Cohn RD, Ross-Barta SE, Westra S, Williamson RA, Hoshi T, Campbell KP: Deletion of brain dystroglycan recapitulates aspects of congenital muscular dystrophy. Nature 2002, 418:422-425

17. Saito F, Moore SA, Barresi R, Henry MD, Messing A, RossBarta SE, Cohn RD, Williamson RA, Sluka KA, Sherman DL, Brophy PJ, Schmelzer JD, Low PA, Wrabetz L, Feltri ML, Campbell KP: Unique role of dystroglycan in peripheral nerve myelination, nodal structure, and sodium channel stabilization. Neuron 2003, 38:747-758

18. Saito F, Blank M, Schroder J, Manya H, Shimizu T, Campbell KP, Endo T, Mizutani M, Kroger S, Matsumura K: Aberrant glycosylation of alpha-dystroglycan causes defective binding of laminin in the muscle of chicken muscular dystrophy. FEBS Lett 2005, 579: 2359-2363

19. Satz JS, Barresi R, Durbeej M, Wukker T, Turner A, Moore SA, Campbell KP: Brain and eye malformations resembling WalkerWarburg syndrome are recapitulated in mice by dystroglycan deletion in the epiblast. J Neurosci 2008, 28:10567-10575

20. Satz J, Philp AR, Nguyen H, Kusano H, Lee J, Turk R, Riker MJ, Hernandez J, Weiss RM, Anderson MG, Mullins RF, Moore SA, Stone EM, Campbell KP: Visual impairment in the absence of dystroglycan. J Neurosci 2009, 29:13136-13146

21. Brockington M, Blake DJ, Prandini P, Brown SC, Torelli S, Benson MA, Ponting CP, Estournet B, Romero NB, Mercuri E, Voit T, Sewry CA, Guicheney P, Muntoni F: Mutations in the fukutin-related protein gene (FKRP) cause a form of congenital muscular dystrophy with secondary laminin alpha2 deficiency and abnormal glycosylation of alpha-dystroglycan. Am J Hum Genet 2001, 69:1198-1209

22. Kobayashi K, Nakahori Y, Miyake M, Matsumura K, Kondolida E, Nomura Y, Segawa M, Yoshioka M, Saito K, Osawa M, Hamano K, Sakakihara Y, Nonaka I, Nakagome Y, Kanazawa Y, Tokunaga K, Toda T: An ancient retrotransposal insertion causes Fukuyama-type congenital muscular dystrophy. Nature 1998, 394: $388-392$

23. Longman C, Brockington M, Torelli S, Jimenez-Mallebrera C, Kennedy C, Khalil N, Feng L, Saran RK, Voit T, Merlini L, Sewry CA, Brown SC, Muntoni F: Mutations in the human LARGE 
gene cause MDC1D, a novel form of congenital muscular dystrophy with severe mental retardation and abnormal glycosylation of alphadystroglycan. Hum Mol Genet 2003, 12:2853-2861

24. Yoshida A, Kobayashi K, Manya H, Taniguchi K, Kano H, Mizuno M, Inazu T, Mitsuhashi $\mathrm{H}$, Takahashi S, Takeuchi M, Hermann R, Straub V, Talim B, Voit T, Topaloglu H, Toda T, Endo T: Muscular dystrophy and neuronal migration disorder caused by mutations in a glycosyltransferase, POMGnT1. Dev Cell 2001, 1: 717-724

25. Beltran-Valero de Bernabe D, Currier S, Steinbrecher A, Celi J, van der Zwaag B, Kayserili H, Melini L, Chitayat D, Dobyns WB, Cormand B, Lehesjoki AE, Cruces J, Voit T, Walsh CA, van Bokhoven H, Brunner HG: Mutations in the O-mannosyltransferase gene POMT1 give rise to the severe neuronal migration disorder Walker-Warburg syndrome. Am J Hum Genet 2002, 71: $1033-1043$

26. van Reeuwijk J, Janssen M, Van den Elzen C, Beltran-Valero de Bernabe D, Dabatelli P, Merlini L, Boon M, Scheffer H, Brockington M, Muntoni F, Huynen MA, Verrips A, Walsh CA, Barth PG, Brunner HG, van Bokhoven H: POMT2 mutations cause alpha-dystroglycan hypoglycosylation and Walker-Warburg syndrome. J Med Genet 2005, 42:907-912

27. Roscioli T, Kamsteeg EJ, Buysse K, Maystadt I, van den Elzen C, van Beusekom E, Riemersma M, Pfundt R, Vissers LE, Schraders M, Altunoglu U, Buckley MF, Brunner HG, Grisart B, Zhou H, Veltman JA, Gilissen C, Manicini GM, Delree P, Willemsen MA, van Bokhoven H: Mutations in ISPD cause Walker-Warburg syndrome and defective glycosylation of $\alpha$-dystroglycan. Nat Genet 2012, 44: $581-585$

28. Willer T, Lee H, Lommel M, Yoshida-Moriguchi T, de Bernabe DB, Venzke D, Cirake S, Schachter H, Vaisar J, Voit T, Muntoni F, Loder AS, Dobyns WB, Winder TL, Strahi S, Mathews KD, Nelson SF, Moore SA, Campbell KP: ISPD loss-of-function mutations disrupt dystroglycan O-mannosylation and cause WalkerWarburg syndrome. Nat Genet 2012, 44:575-580

29. Vuillaumier-Barrot S, Bouchet-Seraphin C, Chelbi M, Devisme L, Quentin S, Gazal S, Laquerrie A, Fallet-Bianco C, Loget P, Odent S, Carles D, Bazin A, Aziza J, Clemenson A, Guimiot F, Bonniere M, Monnot S, Bole-Feysot C, Bernard JP, Loeuillet L, Gonzales M, Socha K, Grandchamp B, Attie-Bitach T, Encha-Razavi F, Seta N: Identification of mutations in TMEM5 and ISPD as a cause of severe cobblestone lissencephaly. Am J Hum Genet 2012, 91:1135-1143

30. Buysse K, Riemersma M, Powell G, van Reeuwijk J, Chitayat D, Roscioli T, Kamsteeg EJ, van den Elzen C, van Beusekom E, Blaser S, Babul-hirij R, van Bokhoven $\mathrm{H}$ : Missense mutations in beta-1,3-N-acetylglucosaminyltransferase 1 (B3GNT1) cause Walker-Warburg syndrome. Hum Mol Genet 2013, 22:1746-1754

31. Manzini MC, Tambunan DE, Hill RS, Yu TW, Maynard TM, Heinzen DL, Shianna KV, Stevens CR, Partlow JN, Barry BJ, Rodriguez J, Gupta VA, Al-Qudah AK, Eyaid WM, Friedman JM, Salih MA, Clark R, Moroni M, Beggs AH, Gabriel SB, Walsh CA: Exome sequencing and functional validation in zebrafish identify GTDC2 mutations as a cause of Walker-Warburg syndrome. Am J Hum Genet 2012, 91:541-547

32. Stevens E, Carss KJ: Mutations in B3GALNT2 cause congenital muscular dystrophy and hypoglycosylation of alpha-dystroglycan. Am J Hum Genet 2013, 92:354-365

33. Lefeber DJ, de Brouwer AP, Morava E, Riemersma M, SchuursHoeijmakers JH, Absmanner B, Verrijp K, van den Akker WM, Huijben K, Steenbergen G, van Reeuwijk J, Jozwiak A, Zucker N, Lorber A, Lammens M, Knopf C, van Bokhoven H, Grünewald S, Lehle L, Kapusta L, Mandel H, Wevers RA: Autosomal recessive dilated cardiomyopathy due to DOLK mutations results from abnormal dystroglycan O-mannosylation. PLoS Genet 2011, 7: e1002427

34. Carss KJ, Stevens E, Foley AR, Cirak S: Mutations in GDP-mannose pyrophosphorylase B cause congenital and limb-girdle muscular dystrophies associated with hypoglycosylation of $\alpha$-dystroglycan. Am J Hum Genet 2013, 93:29-41

35. Barone R, Aiello C, Race V, Morava E, Foulquier F, Riemersma M, Passarelli C, Concolino D, Carella M, Santorelli F, Vieugels W, Mercuri E, Garozzo D, Sturiale L, Messina S, Jaeken J, Fiumara A, Wevers RA, Bertini D, Mattijs G, Lefeber DJ: DPM2-CDG: a muscular dystrophy-dystroglycanopathy syndrome with severe epilepsy. Ann Neurol 2012, 72:550-558

36. Lefeber DJ, Schönberger J, Morava E, Guillard M, Huyben KM, Verrip K, Grafakou O, Evangelou A, Prejiers FW, Manta P, Yildiz J, van den Elzen C, van den Heuvel L, Wevers RA: Deficiency of Dol-P-Man synthase subunit DPM3 bridges the congenital disorders of glycosylation with the dystroglycanopathies. Am J Hum Genet 2009, 85:76-86

37. Yoshida-Moriguchi T, Willer T, Anderson ME, Venzke D, Whyte T, Muntoni F, Lee H, Nelson SF, Yu L, Campbell KP: SGK196 is a glycosylation-specific O-mannose kinase required for dystroglycan function. Science 2013, 341:896-899

38. Brockington M, Yuva Y, Prandini P, Brown SC, Torelli S, Benson MA, Herrmann R, Anderson LV, Bashir R, Burguner JM, Fallet S, Romero N, Fardeau M, Straub V, Storey G, Pollitt C, Richard I, Sewry CA, Bushby K, Voit T, Blake DJ, Muntoni F: Mutations in the fukutin-related protein gene (FKRP) identify limb girdle muscular dystrophy 2I as a milder allelic variant of congenital muscular dystrophy MDC1C. Hum Mol Genet 2001, 10:2851-2859

39. Martin PT: Congenital muscular dystrophies involving the Omannose pathway. Curr Mol Med 2007, 7:417-425

40. Jae LT, Raaben M, Riemersma M, van Beusekom E, Blomen VA, Velds A, Kerkhoven RM, Carette JE, Topaloglu H, Meinecke P, Wessels MW, Lefeber DJ, Whelan SP, van Bokohoven $\mathrm{H}$, Brummelkamp TR: Deciphering the glycosylome of dystroglycanopathies using haploid screens for lassa virus entry. Science 2013, 340: 479-483

41. Chan YM, Keramaris-Vrantsis E, Lidov HG, Norton JH, Zinchenko N, Gruber HE, Thresher R, Blake DJ, Ashar J, Rosenfeld J, Lu QL: Fukutin-related protein is essential for mouse muscle, brain and eye development and mutation recapitulates the wide clinical spectrums of dystroglycanopathies. Hum Mol Genet 2010, 19:3995-4006

42. Blaeser A, Keramaris E, Chan YM, Sparks S, Cowley D, Xiao X, Lu QL: Mouse models of fukutin-related protein mutations show a wide range of disease phenotypes. Hum Genet 2013, 132:923-934

43. Committee for the Update of the Guide for the Care and Use of Laboratory Animals; National Research Council: Guide for the Care and Use of Laboratory Animals: Eighth Edition. Washington, DC, National Academies Press, 2011

44. Chiu YH, Hornsey MA, Klinge L, Jørgenson LH, Laval SH, Charlton R, Barresi R, Straub V, Lochmuller H, Bushby K: Attenuated muscle regeneration is a key factor in dysferlin-deficient muscular dystrophy. Hum Mol Genet 2009, 18:1976-1989

45. Collins CA, Zammit PS, Ruiz AP, Morgan JE, Partridge TA: A population of myogenic stem cells that survives skeletal muscle aging. Stem Cells 2007, 25:885-894

46. Hikida RS: Aging changes in satellite cells and their functions. Curr Aging Sci 2011, 4:279-297

47. Kabaeva Z, Meekhof KE, Michele DE: Sarcolemma instability during mechanical activity in Largemyd cardiac myocytes with loss of dystroglycan extracellular matrix receptor function. Hum Mol Genet 2011, 20:3346-3355

48. Inamori K, Willer T, Hara Y, Venzke D, Anderson ME, Clarke NF, Guicheney P, Bönnemann CG, Moore SA, Campbell KP: Endogenous glucuronyltransferase activity of LARGE or LARGE2 required for functional modification of alpha-dystroglycan in cells and tissues. J Biol Chem 2014, 289:28138-28148

49. Cohn RD, Henry MD, Michele DE, Barresi R, Saito F, Moore SA, Flanagan JD, Skwarchuk MW, Robbins ME, Mendell JR, Williamson RA, Campbell KP: Disruption of DAG1 in differentiated 
skeletal muscle reveals a role for dystroglycan in muscle regeneration. Cell 2002, 110:639-648

50. Jimenez JJ, Bernal JL, del Nozal MJ, Martin MT, Mayo R: Comparative study of sample preparation procedures to determine fipronil in pollen by gas chromatography with mass spectrometric and electron-capture detection. J Chromatogr A 2007, 1146:8-16

51. Krag TO, Hauerslev S, Sveen ML, Schwartz M, Vissing J: Level of muscle regeneration in limb-girdle muscular dystrophy type 2I relates to genotype and clinical severity. Skelet Muscle 2011, 1:31

52. Whalen RG, Harris JB, Butler-Brown GS, Sesodia S: Expression of myosin isoforms during notexin-induced regeneration of rat soleus muscles. Dev Biol 1990, 141:24-40

53. Jimenez-Mallebrera C, Torelli S, Feng L, Godfrey C, Clement E, Mein R, Abbs S, Brown SC, Campbell KP, Kröger S, Talim B, Topaloglu H, Quinlivan R, Roper H, Childs AM, Kinali M, Sewry CA, Muntoni F: A comparative study of alpha-dystroglycan glycosylation in dystroglycanopathies suggests that the hypoglycosylation of alpha-dystroglycan does not consistently correlate with clinical severity. Brain Pathol 2009, 19:596-611

54. Hu Y, Li ZF, Wu X, Lu QL: Large induces functional glycans in an O-mannosylation dependent manner and targets GlcNAc terminals on alpha-dystroglycan. PLoS One 2011, 6:e16866

55. Ware FE, Lehrman MA: Expression cloning of a novel suppressor of the Lec15 and Lec35 glycosylation mutations of Chinese hamster ovary cells. J Biol Chem 1996, 271:13935-13938

56. Hirata T, Fujita M, Kanzawa N, Murakami Y, Maeda Y, Kinoshita T: Glycosylphosphatidylinositol mannosyltransferase II is the ratelimiting enzyme in glycosylphosphatidylinositol biosynthesis under limited dolichol-phosphate mannose availability. J Biochem 2013, 154:257-264
57. Kranz C, Denecke J, Lehrman MA, Ray S, Kreissel G, Sagi D, PeterKatalinic J, Freeze HH, Schmid T, Jackowski-Dohrmann S, Harms E, Marquardt T: A mutation in the human MPDU1 gene causes congenital disorder of glycosylation type If (CDG-If). J Clin Invest 2001, 108:1613-1619

58. Schenk B, Imbach T, Frank CG, Grubenmann CE, Raymond GV, Hurvitz H, Korn-Lubetzki I, Revel-Vik S, Raas-Rothschild A, Luder AS, Jaeken J, Berger EG, Matthijs G, Hennet T, Aebi M: MPDU1 mutations underlie a novel human congenital disorder of glycosylation, designated type If. J Clin Invest 2001, 108:1687-1695

59. Kim W, Choi M, Kim JE: The histone methyltransferase Dot1/DOT1L as a critical regulator of the cell cycle. Cell Cycle 2014, 13:726-738

60. Goddeeris MM, Wu B, Venzke D, Yoshida-Moriguchi T, Saito F, Matsumura K, Moore SA, Campbell KP: LARGE glycans on dystroglycan function as a tunable matrix scaffold to prevent dystrophy. Nature 2013, 503:136-140

61. Hirata A, Masuda S, Ramura T, Kai K, Ojima K, Fukase A, Motoyoshi K, Kamakura K, Miyagoe-Suzuki Y, Takeda S: Expression profiling of cytokines and related genes in regenerating skeletal muscle after cardiotoxin injection: a role for osteopontin. Am J Pathol 2003, 163: 203-215

62. Harris JB, Cullen MJ: Muscle necrosis caused by snake venoms and toxins. Electron Microsc Rev 1990, 3:183-211

63. Harris JB, Grubb BD, Matlin CA, Dixon R: The neurotoxicity of the venom phospholipases A(2), notexin and taipoxin. Exp Neurol 2000, 161:517-526

64. Leschziner A, Moukhles H, Lindenbaum M, Gee SH, Butterworth J, Campbell KP, Carbonetto S: Neural regulation of alpha-dystroglycan biosynthesis and glycosylation in skeletal muscle. J Neurochem 2000, 74:70-80 